\title{
PERBANDINGAN KEMAMPUAN MENYELESAIKAN MASALAH MATEMATIKA PADA PESERTA DIDIK LAKI-LAKI DAN PEREMPUAN KELAS VIII A SMP NEGERI 4 MAMUJU
}

\author{
Suryadi Ishak*, Irmayanti
}

\begin{abstract}
This research is a qualitative descriptive study that aims to compare the ability of male and female students to solve mathematical problems in a two-variable linear equation system. The subjects of this study were 19th grade students A VII from Mamuju Middle School as many as 19 people, then 6 students were taken, consisting of 3 men and 3 women. The results showed that students with high ability categories; (1) able to understand problems; (2) able to complete planning; (3) able to solve problems; (4) can use existing information to re-examine the answers obtained. Whereas in problem solving abilities for students with moderate categories, he is able to stage (1) be able to understand the problem, (2) be able to plan solutions and, (3) be able to solve problems still in stage (4) less able to reexamine the problem solving ability of answers to students with disadvantaged categories. (1) less able to understand problems; (2) inadequate settlement planning; (3) less able to solve problems; (4) unable to use the information available to re-examine the answers obtained. Indicates that the average score of learning outcomes is 75.26. Judging from the number of students who have not finished learning, it can be concluded that the obstacle experienced by students is the lack of students' understanding of the problem given, so that they are not able to solve the problem properly. Men read and understand the problems given at a glance and women understand the problem carefully and analyze whatever information is given correctly.
\end{abstract}

Keywords: Problem solving, systems of linear equations two variables

*) Prodi Pendidikan Matematika, Universitas Al Asyariah Mandar E-mail: suryadiishak@,unasman.ac.id 


\section{PENDAHULUAN}

Kemampuan pemecahan masalah merupakan bagian dari kurikulum matematika yang sangat penting, karena dalam proses pembelajaran maupun mengetahui serta keterampilan yang sudah dimiliki untuk diterapkan pada pemecahan masalah yang bersifat rutin. Berdasarkan hasil penelitian sebelumnya oleh wardan (2012) dengan judul "Kemampuan Pemecahan Masalah Matematika Berdasarkan Perbedaan Jenis Kelamin " menyatakan bahwa Berdasarkan analisis yang telah dilakukan diperoleh bahwa kemampuan pemecahan masalah (SPLDV) ditinjau dari perbedaan dari jenis kelamin yaitu terletak melaksanakan rencana dan memeriksa kembali. Siswa laki-laki tidak mampu melaksanakan rencana dan memeriksa kembali. Sedang siswa perempuan mampu melaksanakan rencana dan memeriksa kembali meskipun kurang lengkap. Usaha yang dilakukan guru untuk meningkatkan kemampuan pemecahan masalah . a) guru memulai pembelajaran dengan masalah kontekstual, bertujuan agar siswa mudah memahami permasalahan. b) guru mengajukan pertanyaan-pertanyaan yang dapat mengembangkan ide siswa. c) guru membiasakan siswa mengemukakan gagasan dan menamnggapi gagasan teman yang lain. d) guru berusaha agar menemukan solusi dari permasalahan tersebut. Jurnal (Febriyanti 2016 ) Dalam memahami masalah siswa laki-laki membaca masalah yang diberikan satu kali, mengungkapkan masalah dengan mengubah letak kata pada kalimat dan tidak mengubah maksud dari masalah, menuliskan atau mengungkapkan semua hal yang diketahui dalam bentuk kalimat, tidak menuliskan dan menyebutkan informasi lain, dalam merencanakan penyelesaian masalah siswa laki-laki memisahkan hal yang tidak diketahui, mencoba-coba untuk menemukan jawaban yang sesuai untuk menyelesaikan suatu masalah, menggunakan rumus yang telah dipelajari sebelumnya, dalam melaksanakan rencana penyelesaian siswa laki-laki mengganti hal tidak diketahui dengan bilangan yang sesuai, menggunakan cara coba-coba untuk memperoleh bilangan yang sesuai, menuliskan jawaban secara langsung tampa menyertakan perthitungan, dalam memeriksa kembali penyelesaian siwa laki-laki menghitung ulang jawaban berdasarkan maslah yang diberikan dan 
meneliti bilangan-bilangannya, menuliskan atau mengungkapkan tafsiran jawaban yang diperoleh dalam sebuah kalimat secara tidak lengkap.

Memahami masalah siswa perempuan membaca masalah yang diberikan lebih dari satu kali,mengungkapkan masalah sama seperti bentuk aslinya dan tidak mengubah sama sekali, menuliskan hal yang diketahui pada sebagian masalah saja, tetapi subjek mengungkapkan semua hal yang diketahui, tidak menuliskan hal yang ditanyakan pada setiap masalah yang diberikan, tetapi siswa perempuan mengungkapkan semua hal yang ditanyakan, tidak menuliskan informasi apapun pada lembar kerja, tapi siswa perempuan menyebutkan sedikit informasi yang ada pada masalah, dalam merencanakan penyelesaian masalah siswa perempuan mencoba coba dan menggunakan metode eliminasi, menggunakan rumus yang telah dipelajari sebelumnya, dalam melaksanakan perencanaan penyelesaian siswa perempuan menggunakan cara coba-coba dan menuliskan bilangan yang sesuai secara langsung tanpa menyertakan perhitungan, menggunakan metode elimnasi untuk menyelesaiakan masalah dan menuliskan secara sistematis, dalam memeriksa kembali siswa perempuan memeriksa kembali jawaban dengan menghitung dan mensubtitusikan jawaban yang diperoleh pada masalah yang diberikan, menuliskan atau mengungkapkan tafsiran dari jawaban yang diperoleh secara lengkap. Berdasarkan uraian di atas, maka penulis berinisiatif melakukan penelitianembadengan judul " Perbandingan Kemampuan Menyelesaikan Masalah Matematika pada Peserta Didik Laki - Laki dan Perempuan pada Peserta Didik kelas VIII A SMP Negeri 4 Mamuju"

\section{Pemecahan Masalah}

Menurut Dahar ( Yudi,2012:29) Pemecahan masalah merupakan suatu kegiatan manusia yang menggabungkan konsep - konsep dan aturan aturan yang telah diperoleh sebelumnya, dan bukanlah suatu kemampuan generik yang dapat diperoleh secara instan. Menilai ranah pemecahan masalah, brarti menilai kompetensi dalam memahami, memilih pendekatan dan strategi pemecahan, serta menyelesaikan masalah. Indikatornya : menunjukan -pemahan masalah; mengorganisasi data dan memilih informasi yang relevan dalam pemecahan masalah; menyajikan 
masalah secara sistematis dalam berbagai bentuk: memilih pendekatan dan metode pemecahan masalah secara tepat; mengembangkan strategi pemecahan masalah ; membuat dan menafsirkan model matematika dari suatu masalah ; menyelesaikan masalah yang tidak rutin. Pemecahan masalah dapat juga membantu siswa mempelajari fakta - fakta, konsep, prinsip matematika dengan mengilutrasikan objek matematika dan realisasinya. Pemecahan masalah merupakan aktivitas dan memberikan tantangan aktivitas bagi kebanyakan siswa serta dapat memotivasi siswa untuk belajar matematika. Memecahkan masalah adalah proses menerapkan pengetahuan yang telah diperoleh sebelumnya kedalam situasi baru yang belum dikenal. Ciri dari soal atau tugas dalam bentuk memecahkan masalah adalah : (1) Ada tantangan dalam materi penugasan, dan (2) masalah tidak dapat diselesaikan dengan menggunakan prosedur yang sudah diketahui oleh penjawab atau pemecah masalah. Kemampuan pemecahan masalah (problem solving) penalaran (reasoning) dan berpikir kritis (critical thinking) merupakan tujuan kritis (critikal gol) dalam pembelajaran matematika. Berdasarkan beberapa pengertian diatas dapat disimpulkan bahwa pemecahan masalah dalam matematika adalah suatu aktivitas untuk mencari penyelesaian dari masalah matematika yang dihadapi dengan menggunakan sebuah bekal pengetahuan matematika yang dimiliki secara integratif.

\section{Kemampuan Pemecahan Masalah}

Kemampuan adalah merujuk pada kinerja seseorang dalam suatu pekerjaan yang bisa dilihat dari pikiran, sikap, dan perilakunya. Pada penelitian ini yang dimaksud kemampuan adalah kesanggupan atau kecakapan yang dimiliki sesorang dalam menyelesaikan suatu soal yang bisa dilihat dari pikiran, sikap, dan perilakunya. Pada umumnya, kemampuan matematika merupakan kemampuan yang telah dimiliki siswa dalam pelajaran matematika. Menurut polya ( 1985 dalam Ali p:2016:21 ) mengartikan pemecahan masalah sebagai satu usaha untuk mencari jalan keluar dari dari suatu kesulitan guna mencapai satu tujuan yang tidak begitu mudah segera untuk dicapai. Tes kemampuan siswa dibagi menjadi :

1. Tinggi 
a. Laki- laki

Dalam memahami masalah siswa laki - laki dapat menuliskan data yang diketahui dengan benar dan lengkap. Dalam menyusun rencana penyelesaian masalah siswa laki - laki mampu menggambarkan masalah dengan symbol /variable dengan benar.

Dalam melaksanakan rencana siswa laki - laki mampu melakukan perhitungan dengan benar. Dalam memeriksa kembali siswa laki laki dapat memeriksa kembali langkah - langkah secara keseluruhan dengan benar.

b. Perempuan

Dalam memahami masalah siswa perempuan dapat menuliskan data yang diketahui dengan benar dan lengkap. Dalam menyusun rencana penyelesaian siswa perempuan mampu menuliskan rumus secara benar. Dalam melaksanakan rencana siswa perempuan mampu menuliskan dan melakukan operasi hitung dengan hasil yang benar dan lengkap. Dalam memeriksa kembali siswa perempuan mampu memeriksa kembali langkah-langkah dengan lengkap.

\section{Sedang}

a. Laki- laki

Dalam memahami masalah siswa laki - laki dapat menuliskan data yang diketahui dengan benar tetapi tidak lengkap. Dalam menyusun rencana penyelesaian masalah siswa laki - laki mampu menggambarkan masalah dengan simbol /variable tetapi kurang tepat. Dalam melaksanakan rencana siswa laki - laki mampu melakukan perhitungan tetapi hasilnya kurang benar. Dalam memeriksa kembali siswa laki - laki dapat memeriksa kembali langkah - langkah secara keseluruhan tetapi kurang lengkap.

b. Perempuan

Dalam menyusun rencana penyelesaian siswa perempuan mampu menuliskan rumus yang sesuai namun hasilnya salah. Dalam melaksanakan rencana siswa perempuan mampu menuliskan dan melakukan operasi hitung dengan hasil yang benar namun kurang lengkap. Dalam memeriksa kembali siswa perempuan mampu 
memeriksa kembali langkah-langkah namun hanya sebagian lengkap.

2. Rendah

a. Laki - laki

Dalam memahami masalah siswa laki - laki tidak dapat menuliskan data yang diketahui dengan benar dan lengkap. Dalam menyusun rencana penyelesaian masalah siswa laki - laki tidak mampu menggambarkan masalah dengan symbol /variable dengan benar. Dalam melaksanakan rencana siswa laki - laki tidak mampu melakukan perhitungan dengan benar. Dalam memeriksa kembali siswa laki - laki tidak dapat memeriksa kembali langkah - langkah secara keseluruhan dengan benar.

\section{b. Perempuan}

Dalam menyusun rencana penyelesaian siswa perempuan tidak mampu menuliskan rumus secara benar. Dalam melaksanakan rencana siswa perempuan tidak mampu menuliskan dan melakukan operasi hitung dengan hasil yang benar dan lengkap. Dalam memeriksa kembali siswa perempuan tidak mampu memeriksa kembali langkah-langkah dengan lengkap.(Eganinta Tarigan.2012:21)

\section{METODE PENELITIAN}

Pada penelitian ini digunakan metode penelitian deskriptif. Penelitian deskriptif adalah memberi gambaran terhadap obyek yang diteliti melalui sampel atau populasi sebagaimana adanya, tampa melakukan analisis dan membuat kesimpulan yang berlaku untuk umum ( Sugiyono : 2014 ). Penelitian deskriptif dapat diartikan sebagai suatu penelitian yang berusaha mendeskrifsikan suatu fenomena/peristiwa secara sistematis sesuai dengan apa adanya.penelitian deskriptif dilakukan untuk memperoleh imformasi mengenai keadaan saat ini. Dalam penelitian semacam itu peneliti mencoba menentukan sifat situasi sebagai mana adanya pada waktu penelitian dilakukan. Penelitian deskriptif kualitatif bertujuan tidak hanya untuk menjelaskan secara menyeluruh masalah yang akan diteliti dan diamati saja,namun ada 
tujuan lain.tujuan dari penelitian deskriptif kualitatif searah dengan rumusan masalah serta pertanyaan penelitian. Hal ini disebabkan tujuan dari penelitian ini akan menjawab dari pertanyaan yang sebelumnya dikemukakan oleh rumusan masalah serta pertanyaan penelitian / identifikasi masalah. Penelitian ini berlokasi SMP Negeri 4 Mamuju,kec. mamuju, kab. Mamuju, prov. sulawesi barat di Binanga Jl.Sukarno Hatta. Subjek dalam penelitian ini adalah siswa kelas VIII A SMP Negeri 4 Mamuju, peserta didik kelas VIII A ini sebanyak 19 orang kemudian diambil 6 orang peserta didik yang terdiri dari 3 laki - laki dan 3 perempuan yang dipilih secara sengaja atau purposive sampling, purposive sampling adalah teknik pengambilan sampel sumber data dengan pertimbangan tertentu.

\section{PEMBAHASAN}

Hasil belajar adalah hasil yang dicapai oleh peserta didik yang telah mengikuti proses belajar mengajar. Hasil pada dasarnya merupakan sesuatu yang diperoleh dari suatu aktivitas, sedangkan belajar merupakan suatu proses yang mengakibatkan perubahan pada individu, yakni perubahan tingkah laku, baik aspek pengetahuannya, keterampilannya, maupun aspek sikapnya. Hasil belajar merefleksikan keluasan, kedalaman, dan kompleksitas pengetahuan, sikap, atau keterampilan seseorang yang digambarkan secara jelas serta dapat diukur dengan teknik-teknik penilaian tertentu. Perbedaan tentang kompetensi dan hasil belajar terdapat pada batasan dan patokan-patokan kinerja siswayang dapat diukur. Hasil belajar erat kaitannya dengan pemahaman, karena hasil belajar diukur dari apa yang telah dipahami oleh siswa dan kinerjakinerja siswa selama dalam proses pembelajaran. pemecahan masalah adalah suatu proses atau upaya untuk merespon atau mengatasi halangan atau kendali ketika suatu jawaban atau metode jawaban belum tampak jelas.

Pada kondisi awal peserta didik kelas VIII A SMP Negeri 4 Mamuju mempunyai hasil belajar matematika yang rendah. Hal ini dikarenakan guru masih kurang optimal dalam memanfaatkan strategi pembelajaran. Pemilihan strategi pembelajaran yang tepat dapat 
meningkatkan hasil belajar matematika. Salah satu pembelajaran aktif yang dapat meningkatkan hasil belajar dalam proses pembelajaran matematika adalah strategi konstektual. Karena strategi metakognitif adalah metode belajar yang mengasah kemampuan peserta didik untuk mengembangkan diri mereka dengan memberi kebebasan untuk mengatur waktu belajar sesuai kebutuhan Dari ketuntasan secara klasikal dapat dilihat bahwa jumlah peserta didik yang belum tuntas belajar sebanyak 5 orang atau $26,32 \%$ dan peserta didik yang belum tuntas sebanyak 14 orang atau $73,68 \%$. Hal ini dapat disimpulkan bahwa pada hasil belajar peserta didik pada pemecahan masalah pada materi sistem persamaan linier dua variabel (SPLDV) belum mencapai ketuntasan 85\% secara maksimal.

Pada gambaran pemecahan masalah dalam penelitian ini, merujuk dari hasil analisis statistik deskriptif dari 19 sampel penelitian ditarik 6 perwakilan sampel untuk menggambarkan kemampuan peserta didik dalam memecahkan masalah yang di kategorikan dalam 3 kategori, tinggi , sedang dan rendah, Dari ke 6 subjek yang di jadikan perwakilan dalam sampel memperlihatkan hasil gambaran utama dalam penyelasaian utama bahwa peserta didik kurang mampu menyelesaikan masalah berdasarkan proses terstruktur, dan peserta didik ke kebayakan kurang teliti dalam memecahkan masalah.

a. Kategori Tinggi

1) peserta didik Laki - Laki

a) Pemahaman Masalah

pada tahap pemahaman masalah, peserta didik laki - laki tidak mampu atau tidak menuliskan informasi yang ada pada soal untuk menjadi syarat cukup dan syarat perlu yang akan digunakan dalam menyelesaikan soal tersebut.

b) Perencanaan Cara Penyelesaian Masalah pada tahap pemecahan masalah, peserta didik laki - laki dapat melakukan rancangan penyelesaian dengan memilih satu metode yaitu metode eliminasi.

c) Pelaksanaan Rencana

Pada tahap pelaksanaan rencana peserta didik laki - laki dapat membuat langkah - langkah pemecahan secara benar 
yaitu dengan melakukan tahap subtitusi dengan memilih salah satu dari variable yang di eliminasi, gambaran yang diperoleh pada tahap 3 pemecahan masalah siswa tersebut terlebih dahulu melakukan eliminasi terhadap variable $y$ dan setelah itu melakukan subtitusi pada variable $\mathrm{x}$ ke persamaan $1(3 x+2 y=15)$. Dalam melaksanakan rencana yang tertuang pada langkah kedua.

d) Peninjauan Kembali

pada tahap pemecahan masalah peserta didik laki laki tidak dapat melakukan peninjauan kembali pada masalah tersebut karna peserta didik laki - laki kurang teliti atau tidak tepat dalam pengoperasian suatu persamaan sehingga hasil yang diperoleh salah.

2) Peserta Didik Perempuan

a) Pemahaman Masalah

Peserta didik perempuan mampu pada tahap pemecahan masalah, siswa tersebut dapat menuliskan hal yang diketahui dan yang ditanyakan dari masalah dan membentuk sebuah persamaan linear. Pada tahap pertama siswa mampu melakukan pemisalan dari Harga bakso (x) dan harga es teh (y) dan siswa membentuk persamaan linear untuk masuk dalam tahap selanjudnya untuk merangcang pemecahan masalah.

b) Perencanaan Cara Penyelesaian Masalah peserta didik perempuan mampu pada tahap pemecahan masalah, siswa tersebut mampu melakukan rancangan penyelesaian dengan memilih satu metode yaitu metode eliminasi.

c) Pelaksanaan Rencana

Pada tahap pelaksanaan rencana peserta didik perempuan melakukan tahap eliminasi dengan memilih salah satu dari variable yang di eliminasi, gambaran yang diperoleh Subjek mampu (Mp) 2 pada tahap 3 pemecahan masalah siswa tersebut terlebih dahulu melakukan eliminasi terhadap 
variable $\mathrm{x}$ dan setelah itu melakukan eliminasi pada variable $y$.

d) Peninjauan Kembali

Untuk tahap meninjau kembali, peserta didik perempuan mampu melakukan peninjauan kembali pada masalah dengan memilih satu persamaan dengan mensubtitusi nilai yang ditemukan dari hasil analisis permasalah.

b. Kategori Sedang

1) Peserta Didik Laki - Laki

a) Pemahaman Masalah

Pada tahap ini siswa laki - laki tidak menuliskan atau tidak mampu menceritakan kembali masalah atau soal dengan bahasanya sendiri.

b) Perencanaan Cara Penyelesaian Masalah

Pada tahap pemecahan masalah, peserta didik laki - laki tidak mampu atau tidak menuliskan keterkaitan antara antar informasi yang ada pada soal.

c) Pelaksanaan Rencana

Pada tahap pelaksanaan rencana peserta didik laki - laki dapat membuat langkah-langkah pemecahan masalah untuk menyelesaikan soal tersebut yaitu dengan melakukan tahap memasukan nilai variable pada persamaan (3) untuk menggantikan nilai variable pada persamaan (2).

d) Peninjauan Kembali

pada tahap pemecahan masalah, kegiatan matematika yang berkaitan dengan proses menemukan suatu pola dari data yang diberikan, kegiatan yang mungkin dilakukan yaitu dengan nilai y pada persamaan (4) menggantikan variable $y$ pada salah satu persamaan awal yaitu persamaan (1) dan peserta didik laki - laki dapat menuliskan hal tersebut.

2) Peserta Didik Perempuan

a) Pemahaman Masalah 
Pada tahap pemecahan masalah, peserta didik perempuan dapat menuliskan hal yang diketahui dan yang ditanyakan dari masalah dan membentuk sebuah persamaan linear. Pada tahap pertama siswa mampu melakukan pemisalan dari yamaha $(x)$ dan honda (y) dan siswa membentuk persamaan linear untuk masuk dalam tahap selanjudnya untuk merangcang pemecahan masalah.

b) Perencanaan Cara Penyelesaian Masalah

Tahap mampu merencanakan cara penyelesaian masalah, peserta didik perempuan mampu menuliskan hubungan antara informasi yang diberikan dengan yang tidak diketahui yang memungkinkan untuk memghitung variabel yang tidak diketahui yaitu dengan menggunakan metode substitusi dengan memilih salah satu dari persamaan yang telah dibentuk untuk melakukan percobaan, kemudian membentuk variable dalam bentuk variable lain.

c) Pelaksanaan Rencana

Pada tahap pelaksanaan rencana peserta didik perempuan keliru atau tidak dapat menggunakan atau membuat langkah - langkah secara benar seharusnya kedua persamaan dikalikan dua dan dieliminasi untuk memperoleh nilai $x$.

d) Peninjauan Kembali

Untuk tahap Mampu meninjau kembali, peserta didik perempuan tidak mampu tahap 4 pemecahan masalah siswa tersebut memperoleh hasil yang salah tetapi dalam cara memasukan nilai y kedalam persamaan sudah betul tetapi hasil yang diperoleh salah karna pada tahap 2 keliru dalam mengeliminasi sebuah persamaan.

c. Kategori rendah

1. Siswa laki - laki

a. Pemahaman Masalah

Pada tahap pemecahan masalah, peserta didik laki-laki tidak dapat menuliskan hal yang diketahui dan yang ditanyakan dari masalah dan membentuk sebuah 
persamaan linear. Pada tahap pertama siswa kurang mampu memahami soal yang ada Perencanaan Cara Penyelesaian Masalah

b. Pelaksanaan Rencana

Pada tahap pelaksanaan rencana peserta didik laki - laki dapat menggunakan atau membuat langkah - langkah secara benar

c. Peninjauan Kembali

Untuk tahap Mampu meninjau kembali, peserta didik laki laki tidak mampu tahap 4 pemecahan masalah siswa tersebut memperoleh hasil yang salah

d. Perencnaan cara penyelesaian masalah

Untuk tahap kurang Mampu meninjau kembali, peserta didik laki - laki salah dalam menentukan atau menyelesaikan perkalian harga apel dan harga mangga

2. Siswa perempuan

a. Pemahaman masalah

Pada tahap pemecahan masalah, peserta didik perempuan tidak dapat menuliskan hal yang diketahui dan yang ditanyakan dari masalah dan membentuk sebuah persamaan linear. Pada tahap pertama siswa kurang mampu memahami soal yang ada Perencanaan Cara Penyelesaian Masalah

b. Pelaksanaan rencana

Pada tahap pelaksanaan rencana peserta didik perempuan masih belum dapat menggunakan atau membuat langkah langkah secara benar

c. Peninjauan kembali

Untuk tahap Mampu meninjau kembali, peserta didik perempua mampu tahap 4 pemecahan masalah siswa tersebut memperoleh hasil yang benar.

d. Perencanaan cara menyelesaikan masalah

Untuk tahap kurang Mampu meninjau kembali, peserta didik perempuan benar dalam menentukan atau menyelesaikan pekerjaan yang ada 
Tabel 1. Subjek Kemampuan Pemechan Mnasalah SPLDV Kelas VIII A

\begin{tabular}{||c|c|l|c||}
\hline \hline Kategori & No & \multicolumn{1}{|c|}{ Nama } & Nilai \\
\hline \multirow{2}{*}{ Tinggi } & 1 & Muhammad Ihwan & 90 \\
\cline { 2 - 4 } & 2 & Dewi Aulia Sartika & 90 \\
\hline \multirow{3}{*}{ Sedang } & 3 & Taufik Isbullah & 75 \\
\cline { 2 - 4 } & 4 & Fitri & 75 \\
\hline \multirow{2}{*}{ Rendah } & 5 & Anwar & 65 \\
\cline { 2 - 4 } & 6 & Sukmawati & 65 \\
\hline
\end{tabular}

\section{SIMPULAN}

Dalam penelitian ini, dapat di simpulkan bahwa hasil belajar sisiwa laki-laki lebih rendah daripada siswa perempuan dalam mata pelajaran matematika kelas VIII A Semester Ganjil materi sistem persamaan linear dua variabel di SMP Negeri 4 Mamuju, Kendala yang dialami siswa laki-laki adalah kurangnya pemahaman terhadap masalah yang diberikan, sehingga tidak mampu menyelesaikan masalah yang diberikan dengan baik. Sedangkan perempuan kurang percaya diri dan berterus terang ketika menyampaikan pendapat padahal dugaan yang disampaikan sudah tepat. berkemampuan kategori tinggi cenderung memiliki proses pemecahan masalah yang teliti. Sedangkan untuk kelompok peserta didik berkemampuan sedang cenderung memiliki proses pemecahan masalah yang cukup teliti. Untuk kelompok peserta didik berkemampuan rendah cenderung memiliki proses pemecahan masalah yang kurang teliti, kendala utama peserta didik dalam proses pemecahan masalah kurang mampu menyatakan langkah-langkah terstruktur yang ditempuh dalam menyelesaikan soal menggunakan konsep yang dipelajari pada materi sistem persamaan linear dua variabel. 


\section{DAFTAR PUSTAKA}

Ali.P.Muhammad. 2016. Strategi Pemecahan Masalah Matematika. Polewali

Amrulloh. 2012. Pengaruh Penerapan Model Kooperatif Tipe Number Head

Together Terhadap Prestasi Belajar Siswa Kelas XI SMA Negeril Wanasaba.

Arikunto, Suharsimi.2006. Prosedur Penelitian.Jakarta:Pt. Asdi Mahasatya.

Kurnia Wardani, Asizah. 2014. Kemampuan Pemecahan Masalah Matematika Berdasarkan Jenis Kelamin. Jurnal Pendidikan Matematika STKIP PGRI Sidoarjo Vol.2, No.1, Hal. 99.

Aunurrahman. 2012. Belajar dan Pembelajaran. Bandung: Alfabeta. Chaeruddin. 2001. Proses Belajar mengajar. Jakarta: Pustaka Sinar. Depdikbubnas.2014. Matematika Kelas X. Jakarta. Erlangga.

Eganinta Tarigan. 2012. Analisis Kemampuan Pemecahan Masalah Matematika Berdasarkan Langkah - Langkah Polya Pada Materi Sistem Persamaan Linier Dua Variabel Bagi Siswa Kelas VIII SMP Negeri 9 Surakarta ditinjau dari Kemampuan Penalaran Siswa.

Febriyanti, Rahma. 2016. Profil Pemecahan Masalah Matematika Siswa dalam Menyelesaikan Soal Cerita ditinjau dari Perbedaan Jenis Kelamin. Ejournal.uin-malang.ac.id.Vol 2, No.2, Halaman 95.

Hamalik, Oemar. 2001. Proses Belajar Mengajar. Bandung. Bumi Aksara. Nasution, 2012. Didaktik Asas-Asas Mengajar. Jakarta: Bumi Aksara.

Purwanto. 2011. Evaluasi Hasil Belajar. Yogyakarta. Pustaka Pelajar. Ratumanan, T. G. 2004. Belajar dan Pembelajaran. Surabaya: University Press.

Riyanto, Yatim. 2010. Paradigma Baru Pembelajaran. Jakarta: Kencana. 
Ratumanan dan Laurens. 2006. Evaluasi Belajar Yang Relevan dengan

Kurikulum Berbasis Kompetensi. Surabaya: YP31T dan Unesa University Press.

Rusman. 2011. Model-model Pembelajaran. Jakarta. PT. Raja Grafindo Persada.

Sahabbudin. 1999. Mengajar dan Belajar Dua Aspek Dari Suatu Proses

Yang Disebut Pendidikan. Makassar. UNM Makassar.

Sinta. 2009. Pemecahan Masalah Matematika Siswa dalam Menyelesaikan

Soal Cerita. Ejournal.uin-malang.ac.id.Vol 1, No.2, Halaman 90

Sugiono. 2014. Metode Penelitian Kombinasi. Bandung: alfabeta.

Suprijono, Agus. 2009. Cooperative Learning. Yogyakarta. Putaka Pelajar.

Arifin (2009).identifikasi kemampuan matematika siswa dalam

memecahkan masalah aljabar di kelas VIII berdasarkan

taksonomi SOLO jurnal MATHhudenesa,2 (1). 1-8 di akses pada lamar http://

jurnalmahasiswa.unesa.ac.id/article/2368/30/article.pdf

Syah, Muhibbin. 2000. Psikologi Pendidikan Dengan Pendekatan Baru (rev.ed). Bandung. Remaja Rosda Karya.

Trianto. 2009. Mendesain Model Pembelajaran Inovatif-Progresif. Jakarta. PT. Fajar Interpratama Mandiri.

Yudi. 2012. Pemecahan Masalah Matematika Siswa dalam Menyelesaikan Soal Cerita pada sekolah SMA Negeri 1 malang. Ejournal.uinmalang.ac.id.Vol 1, No.1, Halaman 29. 